Filip Kubiaczyk

(Poznań-Gniezno)

https://orcid.org/0000-0003-4124-6480

\title{
SATIRE IN THE SERVICE OF HISTORY. ON THE PHENOMENON OF TABARNIA IN CATALONIA ${ }^{1}$
}

\begin{abstract}
The paper analyzes the phenomenon of Tabarnia, a grassroots social movement aiming to expose and counter the absurdities of the Catalan independence nationalism. The adherents of Tabarnia employ irony, situational humour, performance and historical re-enactment to ridicule and neutralize the nationalist discourse.
\end{abstract}

\section{Key words}

Tabarnia, Catalonia, Tabarnia is not Catalonia, Albert Boadella, satire, irony, Catalonian nationalism, tabarneses, Tabarnexit

There can be no doubt that Spain's greatest political problem today is the situation in Catalonia which, governed by the nationalist faction, clearly strives for secession. The Spanish State faces a serious structural problem, which stems from the traditional conflict between unionists and federalists. Although the Constitution of Spain of 1978 affirms it to be a united state based on autonomies, the example of Catalonia demonstrates that the issue persists. As a by-product of that process, a grassroots social movement emerged in Catalonia, whose goal is to counter the nationalist project by ridicule and tongue-in-cheek mimicking. Tabarnia, as the movement is called, has not only attracted numerous Catalans

1 This paper has been developed as part of the National Centre for Science grant (MINIATURA 1); no. 2017/01/X/HS3/00689. 
but also Spaniards. What started as a joke, transformed with time into a powerful social weapon, which stirred up nervous reactions among the nationalists. It would therefore be justified to speak of the phenomenon of Tabarnia, which naturally leads to questions concerning the effectiveness of its strategy. Tabarnia is not a political movement and possesses no real agency, but given the absence of a sensible dialogue between Catalonia and Spain, its greatest strength proved to be in exposing the absurdities of the Catalan nationalism to all inhabitants of Catalonia. Although Tabarnia's strategy represents a form of soft resistance it became a mirror of nationalism, which surpassed the expectation of the originators and the adherents of the movement. As a fictitious initiative whose daily activities are limited chiefly to social media, Tabarnia won the support of numerous residents of Catalonia, while thanks to various channels through which it reaches the audience, its idea gained popularity in Spain, and went on to be recognized in Europe and the world. Besides debunking the absurd notions that Catalan nationalist draw upon in their discourse, the Tabarnia project demonstrates that there exists a substantial community of citizens in Catalonia who see themselves as Catalans and Spaniards simultaneously. It also shows how much can be achieved by resorting to social engineering. As it turns out, buffoonery and satire offer an effective measure against the secessionist projects of the nationalists.

\section{JOKE AS A TOOL IN THE FIGHT AGAINST NATIONALISM}

Before embarking on an analysis of Tabarnia's strategy, one should first outline the context in which that exceptional social movement emerged and explain its essential premises. In the first place, it has to be noted that the name of the movement - derived from the names of the two Catalan provinces, Tarragona and Barcelona - as well as its concept originated in 2013 with Daniel de la Fuente, a resident of Barcelona ${ }^{2}$. He also came up with the flag, the coat of arms, the logos and the map of Tabarnia, and developed the platform Barcelona is not Catalonia. It was in the social media channels of the latter that information about two parts of Catalonia was posted in 2015. It is worth noting that the very fact of associating Tabarnia with the territory of Barcelona and Tarragona is an ironic one. The heart of the matter is that the present-day territory was established in an ordinance issued by Javier de Burgos in 1833, and it does not overlap with the medieval county of Barcelona, to which the nationalists have usually referred in their identity and independence-oriented projects. These two territories were alleged to be distinctly

\footnotetext{
2 ¿Quién inventó Tabarnia? However, it needs to be noted that antecedents of the movement can be traced back to 2007. On that issue see Tabarnença. El 23 de abril queda fijado como el Día de Tabarnia.
} 
different in terms of their economy, social structure, language, identity and populations. The year 2017 saw the creation of the Platform for Tabarnia (Plataforma por Tabarnia); alongside, the domain name tabarnia.org was registered as well ${ }^{3}$. According to Daniel de la Fuente, supporters of Tabarnia use the name to denote a territory which should split from Catalonia. After all, one easily notices that:

apart from the rural Catalonia - predominantly in favour of independence, relying on local economy, obsessed with identity, and hostile towards the Castilian tongue - there exists a cosmopolitan Catalonia, proudly bilingual, urban, multicultural, and maintaining a strong bond with the rest of Spain and Europe ${ }^{4}$.

This rift within Catalonia itself is a fact which the nationalist propaganda seeks to conceal, while the Tabarnia project attempts to undermine such efforts. The idea is to show what is happening in Catalonia to the rest of the Catalan community, Spain, and the entire world. The media resonance that the project generated went well beyond what its creator might have expected ${ }^{5}$ and made the name known throughout the world. De la Fuente successfully implemented social engineering techniques which consisted in composing fictitious interviews, creating drawings, photomontages and slogans circulated in the media, or staging social rallies, as e.g. on October $12^{\text {th }}$, during Spain's national day. These gatherings are to attest to real and strong support for Tabarnia among the Catalan community. As a result, de la Fuente "created an illusion of reality in which people demonstrated (during the holiday) with banners and slogans"6. The success of the project went as far as prompting certain Spanish brands to start using the label "Made in Tabarnia"; articles concerned with Tabarnia appeared in Spanish press, followed by European and international outlets, people began to buy and display flags of Tabarnia in the public space, while a separate entry for Tabarnia was published in Wikipedia ${ }^{7}$. The publicity reached its peak on December $26^{\text {th }}, 2017$, when the term "Tabarnia" became a global trending topic, a most-searched word online ${ }^{8}$. Considering the above, Tabarnia may be legitimately defined as an undertaking oriented towards a specific goal and using a particular strategy: the deliberate work of one man who gave it shape and, in order to carry it out, invited well-known and popular persons who are explicitly critical of the Catalan nationalism, such as Jaume Vives (journalist, activist, and writer), or Albert Boadella (actor, dramatist and former direc-

\footnotetext{
3 Alandete, Baquero 2017.

4 Arrufat 2015.

5 See Entrevista al creador de Tabarnia, Daniel de la Fuente en Espejo Público, 2018.

${ }^{6}$ ¿Quién inventó Tabarnia?

7 Ibidem.

8 Tabarnença. El 23 de abril queda fijado como el Día de Tabarnia.
} 
tor of the Els Joglars theatre). The former became the "spokesman" of Tabarnia, the latter its "president". Tabarnia was also joined by Joan López Alegre, former member of the Parliament of Catalonia from the People's Party, a person called "the quiet/peaceful Catalan" (el català tranquil).

The neologism "Tabarnia", coined to denote a useful tool devised to counter separatism, serves as an appellation of the regions spanning the metropolitan area of Barcelona, Tarragona, and the land between them. The existence of such a territory can be asserted as it does have certain characteristics which set it apart from the rest of Catalonia (an autonomous community in which it is incorporated), notably the desire to remain a part of Spain ${ }^{9}$. As a term, Tabarnia has expanded semantically in relation to the current political situation and developments in Catalonia, yielding new forms and meanings. One of those is tabarning which stands for removal of the independence symbols from Catalan public spaces, i.e. streets, public buildings, roads etc. ${ }^{10}$ Adherents of Tabarnia claim that it takes advantage of the very instruments exploited by Catalan nationalists, which allows it to mimic their project. Naturally, it does not mean that the actions of the nationalists are iterated by Tabarnia, as humour is its essential weapon ${ }^{11}$. "The president of Tabarnia" is aware that its success lies in the fact that it differs substantially from its adversary, owing in particular to lack of political representation. If Tabarnia transformed into a political party, it would follow the path of the nationalists. The awareness of being the opposite of Catalan nationalists seems to be fundamental to the understanding of the phenomenon of Tabarnia, which does not want to repeat the mistakes of the nationalists, nor engage in politics. Its true calling is in effective civic parody which irks the nationalist faction, causing fits at the very mention of Tabarnia ${ }^{12}$. Boadella does not hesitate to refer to Catalan nationalists as a sect, because sects have no sense of humour ${ }^{13}$. For him, use of satire as the principal weapon is the upshot of the loss of such a sense in nationalist Catalonia, which feeds instead on xenophobia: the conviction that Catalonia and the Catalans are better than Spain and Spaniards.

What are the outcomes of that strategy? In a sense, we are dealing with duplication which brings Baudrillard's notions of simulation and simulacra to mind ${ }^{14}$. Tabarnia would thus be an alter ego of Catalan nationalism, a sign of a new yet non-existent autonomous community in Spain, which draws on another sign of a non-existent Catalan republic supported only by a percentage of the inhabit-

\footnotetext{
9 ¿Qué es Tabarnia? El verdadero origen del movimiento.

10 Tabarning: el deporte ecológico de moda en Tabarnia.

${ }^{11}$ Boadella 2018, p. 159.

${ }^{12}$ Ibidem, p. 167-169.

13 See Delgado Sánz 2018.

${ }^{14}$ Baudrillard 1981.
} 
ants of Catalonia. This is an example of a purely semiotic play, where one signs functions by relating to another. To a degree, Tabarnia is hyperreal, existing only virtually ${ }^{15}$ and solely through reference to the project of the independent Catalan republic; hence, were it not for the nationalist project, Tabarnia would have no reason for being (virtual though it is). Rafa Latorre is therefore correct confining the essence of Tabarnia to "rhetorical play" (un juego retórico), in which he sees the source of strength of the project as well as its weakness, as it risks becoming a victim of a similar rhetorical play, especially if Tabarnia sought to materialize itself ${ }^{16}$. Let us note that even though it has not been formally constituted, internal "cracks" in its virtual being have already appeared. The examples one could cite here include Catabàrnia ${ }^{17}$, Balearnia ${ }^{18}$, Geronia ${ }^{19}$, or Palmarnia ${ }^{20}$, neologisms created in the wake of Tabarnia's success. Thus Latorre's vision has come true in the virtual space, based on which it may be presumed that the same would happen in reality.

\section{BETWEEN VIRTUALITY AND REALITY}

From the outset, Tabarnia has functioned as an idea intended to reach the broadest possible audience, so that its popularity would make it a viable rival to the project of Catalan nationalists. The following describes the most important areas in which Tabarnia's extensive presence confounded its opponents.

First and foremost: presence in social media. Creators of Tabarnia realized that they do not have access to such a powerful instrument of ideological propaganda

15 Still, Javier Barraycoa cites a number of arguments, including historical ones, in favour of actual existence of Tabarnia. See Argumentos histórico-políticos para la independencia de Tabarnia, Anotaciones de Javier Barraycoa, 2017.

${ }^{16}$ Latorre 2017.

17 Catabàrnia denotes those constituencies of Tabarnia (Sant Cugat del Vallès, Vilafranca del Penedès, Tossa de Mar, Valls, Molins de Rei, Sant Just Desvern, Castellar del Vallès, Montgat, El Masnou, La Garriga), where independence parties won majority of votes during the elections to the Catalan parliament on December 21st, 2017, and represent 50 per cent of its inhabitants. See ¿Qué diablos es Catabàrnia?, 2018.

${ }^{18}$ Balearnia is a project opposing the designs of Catalan nationalists, in whose discourse the Baleares are invariably included in the concept of the so-called "Catalan countries". Amorós 2018.

${ }^{19}$ Geronia is a project conceived by the residents of Gerona, one of the four Catalan provinces which make up the autonomous community of Catalonia, with the aim of defending the Spanishness of that territory; it presupposes creation of Spain's new, 19th autonomous community in response to the establishment of Tabarnia. Nace Geronia, la plataforma para reivindicar la españolidad de Gerona, 2018.

${ }^{20}$ Palmarnia is an intellectual provocation based on the claim that Palma, the capital of Mallorca, should be separate from the island. Palma, the modern and cosmopolitan heart of the island, a cultural and economic centre with good infrastructure, education and health care tends to be - in the opinion of some - poorly governed by people from outside the city. Delgado 2018. 
as television, especially Catalan TV3, which is widely believed to be a mouthpiece of Catalan nationalists, therefore they focused their attention on social media as a greatly convenient channel to communicate with the people of Catalonia. Information concerning Tabarnia is available on its website, tabarnia.org, on Facebook profiles such as Plataforma por Tabarnia ${ }^{21}$, Gente de Tabarnia ${ }^{22}$, or Barcelona is not Catalonia $^{23}$, and Twitter accounts: Tabarnia Oficial - Plataforma por Tabarnia ${ }^{24}$, Tabarnia Today ${ }^{25}$ and "Government of Tabarnia" (Govern de Tabàrnia) ${ }^{26}$. It was thanks to social media that many Catalans as well as numerous outside observers found out about the existence of Tabarnia. The latter is in fact the sum total of electronic platforms, social networks, and websites ${ }^{27}$ promoted and endorsed by those Catalans who do not wish to live in a nationalist Catalonia ${ }^{28}$. Using such media, the supporters of Tabarnia post information, images and videos which not only report on the current events in Catalonia, but also provide an important source of information that is free of nationalist propaganda. Tabarnia is also present on You Tube where, among other things, one can watch the speeches of "the president of Tabarnia", Albert Boadella. All this is designed to convince Catalans - using Levinson's soft edge ${ }^{29}$ - that information supplied by Catalan nationalists are not the sole truth about Catalonia. In this fashion, one attempts to overcome the hegemonic narratives of the nationalists in the social space of Catalonia, to effect a positive implosion of meaning, to draw on Baudrillard ${ }^{30}$. The information circulated by the Tabarnists undermines the negative picture of Spain and things Spanish painted by Catalan nationalists, neutralizing its impact. In other words, a communication relying on satire and joke invalidates the communication based on manipulation and concealment.

Secondly: the existence of the symbols of Tabarnia. Tabarnia has its own flag and coat of arms. The flag has four sections: the first and the fourth feature the cross of St. George, patron of Catalonia and the symbol of the former Crown of Aragon, which represents Lower Tabarnia (la Baja Tabarnia) with its capital in Barcelona, while the second and third fields bear four modified red lines - taken from the Aragon coat of arms of the which stand for Upper Tabarnia (la Alta

\footnotetext{
21 Tabarnia ORG 2019.

22 Tabarnia Group 2019.

23 Barcelona is not Catalonia 2018.

24 Barcelona is not Catalonia 2019a.

25 Tabarnia Today 2019.

26 Govern de Tabàrnia.

27 Dolça Catalunya 2019.

28 González 2018.

29 Levinson 1998.

30 See Baudrillard 1981, pp. 119-129.
} 
Tabarnia) with its capital in Tarragona. In the opinion of the Tabarnists, the flag has a deeper historical foundations than the estelada of the independence movement. The blazon of Tabarnia situated in the centre, showing St. George taming the dragon of independentism and the slogan ACTA EST FABULA (lit. "the farce is over") which had been the usual formula used in ancient Rome upon the end of a theatrical performance (a similar phrase - això s'ha acabat - was employed by Carles Puigdemont who spoke thus of the Catalan independence process ${ }^{31}$ ). In the light of Michael Billig's theory, the flag of Tabarnia functions as a metonymy ${ }^{32}$ and serves to flaunt Spanish nationality in the public space by manifesting Catalanness - a complement and a component of the former, not an antithesis. Besides the flag and the coat of arms there is also the Day of Tabarnia (La Diada de Tabarnia, El Día de Tabarnia ${ }^{33}$ ), celebrated on April $23^{\text {rd }}$ which is the holiday of St. George, the patron of Catalonia. This is when the supporters of Tabarnia are expected to hang or mount the flags on their balconies ${ }^{34}$. However, personal observation of this author suggests that the flag of Tabarnia (fig. 1) occurs only sporadically in the public space of Barcelona and Tarragona, which hampers effective competition with the Catalan senyera and estelada ${ }^{35}$.

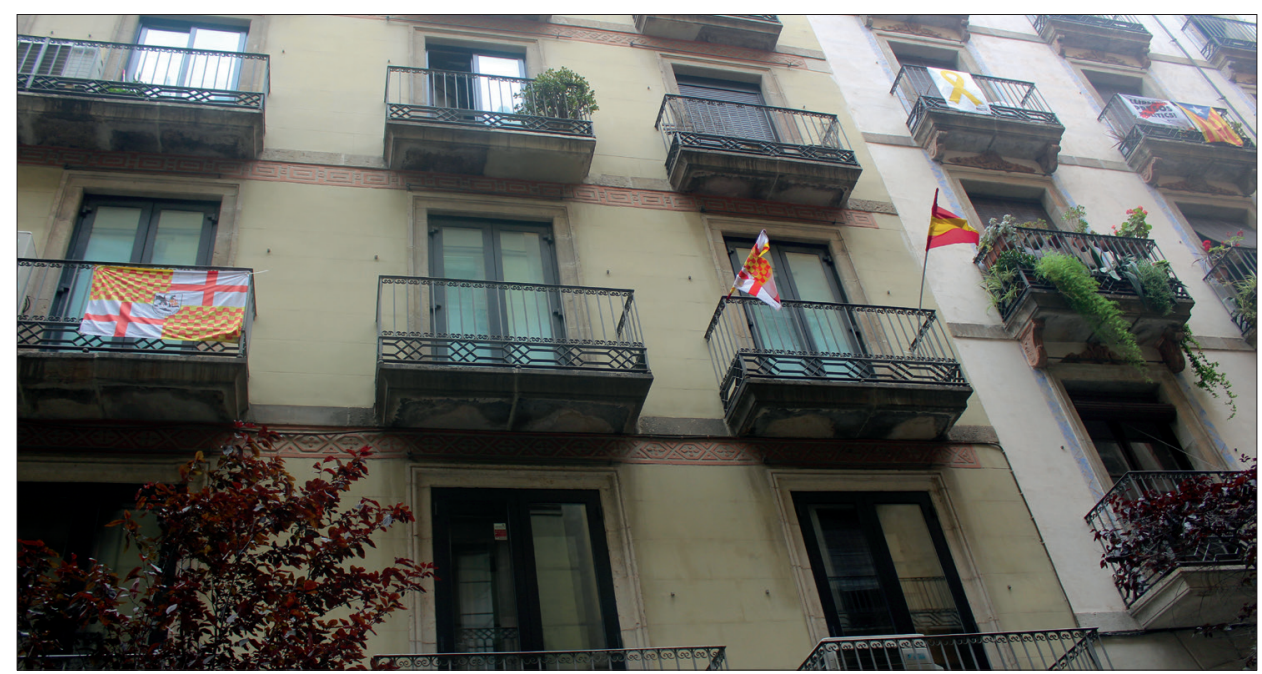

Fig 1. The flag of Tabarnia on one of the buildings in Barcelona

Source: photographs by the author

31 Tabarnença. El 23 de abril queda fijado como el Día de Tabarnia.

32 Billig 2008, p. 89.

33 Tabarnença. El 23 de abril queda fijado como el Día de Tabarnia.

34 Bandera de Tabarnia oficial; Tabarnença. El 23 de abril queda fijado como el Día de Tabarnia.

35 On the war of symbols in the public space of Catalonia see Kubiaczyk 2018. 
Thirdly: availability of Tabarnia-related merchandise, which can be purchased on its website. Apart from the flag, the online shop offers the first political map of Spain on which Tabarnia is indicated as a new autonomous community ${ }^{36}$, $\mathrm{t}$-shirts in various colours with the coat of arms of Tabarnia, or a slogan which enjoys quite a popularity among the opponents of the separatists: "The Republic does not exist, you idiot!" (La República no existe, idiota!), as well as hoodies, mugs, pins or a scarf ${ }^{37}$ with Tabarnia's emblem. Also, for a price of $€ 25$ one can order a Tabarnia identity card (Documento Regional de Identidad de Tabarnia), issued by the officially registered association Platform for Tabarnia (Plataforma por Tabarnia Oficial). The document states the name of the new autonomous community, shows the contours of its territory, the coat of arms and the flag, as well as contains personal data of the holder (first and last name, date of birth), their picture, signature, expiry date and personal identity number (DNI); the name of the document is stated in Spanish, Catalan and English ${ }^{38}$. Purchase of the document does not require Spanish citizenship or membership in any particular association. The document is valid for a period of five years. The existence of such merchandise increases the visibility and popularity of the movement in Catalonia and the entire Spain. It may be considered an example of commodity patriotism or patriotism-targeted marketing, which enables creators of Tabarnia to monetize on the social idea they propagate.

Fourth: criticism of Tabarnia voiced by its opponents. There can hardly be a better proof of the visibility and popularity of Tabarnia in Catalonia than the criticism it receives from those whose absurd claims and manipulations it openly exposes. Those are the critics of Tabarnia who attest to its success, simultaneously taking counteraction to stigmatize the movement, underlining forcibly that it is a fiction which the Spanish media attempt to lend the status of something real, as a convenient instrument for promoting the idea of Spanish nationalism ${ }^{39}$. The degree to which Tabarnia manages to annoy nationalists is evinced for instance in what Adam Majó from the Catalan Generalitat said in Tot es Mou, a TV3 show. Majó stated that since January $1^{\text {st }}$, 2017, 328 acts of aggression had been committed in Catalonia by the paramilitary groups of the Spanish extreme right. When enumerating those groups, he mentioned none other than Tabarnia, showing its logotype. This eloquently demonstrates that Catalan nationalists began to treat seriously the satirical faction from whose critical sting proved sharp indeed.

\footnotetext{
${ }^{36}$ Mapa de Tabarnia. Ya está disponible el primer mapa de España que incluye Tabarnia.

37 Tabarnia - Tienda 2019.

${ }^{38}$ Ya se puede adquirir el Documento Regional de Indetidad de Tabarnia, el "DNI de Tabarnia".

39 Cf. La Constitución es el último salvavidas de Tabarnia; Nuevo ataque de la Generalitat de Cataluña contra Tabarnia.
} 
Fifth: attempts of political parties to exploit the popularity of Tabarnia. This was the case with the xenophobic party Platform for Catalonia (Plataforma per Catalunya), which in 2017 registered the name Plataforma per Tabarnia as one of its alternative designations. In response, Miguel Martínez, leader of the Platform for Tabarnia said that many parties would like to take advantage of the renown that Tabarnia had gained, but it would not get involved in politics, because it merely wished to parody independentism ${ }^{40}$. This is not an isolated example of political parties trying to use the popularity of the brand for the needs of their electoral campaigns, as a similar situation took place with the association Coordinadora por Tabarnia ${ }^{41}$.

\section{TABARNIA'S MIMETIC GAMES}

The fundamental motive behind all actions of Tabarnia is the fight for memory and a particular vision of Catalonia's past. As Albert Balcells underlines, "there is no identity without memory, and there is no memory without a policy of memory"42. Catalan adherents of Tabarnia who at the same time feel and consider themselves to be Spanish, resort to parody of the discourse of Catalan nationalists, to historical reconstruction or performance art, all with a view to abolishing the nationalist vision of the past of Catalonia and its associated symbols, seeking to supplant them with their vision and their symbols, in which the Catalanness of Tabarnia is invariably an element and a part of being Spanish. In other words, Tabarnia is a way to express what is Catalan by means of what is Spanish. Thus they engage in symbolic rivalry for the Catalan past and identity with Catalan nationalists. After all, as Pierre Nora observes:

History, on the other hand, is the reconstruction, always problematic and incomplete, of what is no longer. Memory is a perpetually actual phenomenon, a bond tying us to the eternal present; history is a representation of the past (...). History is perpetually suspicious of memory, and its true mission is to suppress and destroy it (...). History's goal and ambition is not to exalt but to annihilate what has in reality taken place. ${ }^{43}$.

Bearing that difference between history and memory in mind, the Tabarnists undertook a range of actions to ridicule, mimic and, as a result, debilitate the project of Catalan nationalists. The most important of those counteractions are discussed below.

\footnotetext{
40 Tomàs, Puente 2018.

41 Ibidem.

42 Balcells 2008, p. 45.

43 Nora 2008, pp. 20-21.
} 
In January 2018, a video was uploaded to YouTube in which Albert Boadella, "president of Tabarnia in exile", delivered an address in Catalan to the citizens of Tabarnia. The face of the podium from which he spoke bore the inscription "government of Tabarnia", with the flag and coat of arms of Tabarnia underneath. Behind him, there stood the flags of the European Union, Spain, and Tabarnia. Boadella began his speech thus: "Citizens of Tabarnia. I am not here. I am not here (in Catalonia) because the usurpers of feelings, money, institutions, clubs, and flags have made that territory unliveable to those who cherish freedom and sense of humour" ${ }^{\prime 4}$. These words were a direct reference to what Josep Taradellas (1899-1988), president of the Generalitat, said to the people of Catalonia in 1977 upon his return from exile: "Citizens of Catalonia, I am already here!" Boadella's declaration was supposed to draw attention of the listeners to the fact that he, as a "president of Tabarnia", had long been staying outside Catalonia due to social and political situation in the region, a situation for which Catalan nationalists are responsible. He then asserted that nationalists had divided Catalonia, tore families and friendships apart, and were leading it into ruin. Hence, Tabarnia was a kind of antibody contributing to the revival of the sense of Catalan community. In closing, Boadella added: "Long live Tabarnia, which is the same as saying long live Spain!" ${ }^{45}$

In March 2018, Tabarnia organized a demonstration at the monument of Rafael Casanova (1660-1743), an important hero of the nationalist discourse, who was injured in 1714 fighting against the Bourbons, but survived and lived after the war in Barcelona, working as an attorney. For many Catalans Casanova is an exclusively Catalan hero, a view which is not shared by Spaniards who have reasons to think otherwise. After all, he did not die a martyr's death on the battlefield, and fought not so much defending Barcelona and Catalonia but Spain and its Habsburg king. On each anniversary of those events, falling on September $11^{\text {th }}$, Catalans lay flowers at the monument of Casanova, associating the figure with the martyrological and nationalist vision of Catalonia, which aggravates those Catalans who feel Spanish and consider Casanova a Spanish rather than solely Catalan hero. Representatives of Tabarnia oppose the distorted nationalist vision of Catalonias past. According to Boadella, history is being manipulated by the nationalists "in order to forge a symbol which has nothing to do with reality. The aim is a perverse one: to incite hate and xenophobia against the Spanish, alleging their responsibility for the injustices even today" ${ }^{36}$. For this reason, the Tabarnists decided to forestall the nationalists and laid the flowers first, on March $4^{\text {th }}$. The fact that one of the persons to lay the flowers was Eduardo de Delás, Rafael Casano-

\footnotetext{
${ }^{44}$ Discurso del presidente de Tabarnia, Albert Boadella 2018.

45 Ibidem.

${ }^{46}$ Boadella 2018, p. 47.
} 
va's descendant, was perceived as highly symbolic. Also, emblems of Tabarnia and Spain were placed around and on the monument itself. The people gathered there displayed banners with pro-Spanish and anti-nationalist slogans, such as "I defend

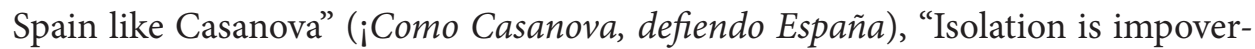
ishment!” (¡Aislarse es empobrecerse!), "We are and we will be Spanish!” (¡Somos y seremos españoles!) and chanted "Catalonia is Spain!” (¡Cataluña es España!), "Puigdemont belongs in prison!” (¡Puigdemont a prisión!), "Boadella, the president!” (¡Boadella, presidente!), “I am Spanish!” (¡Soy español!), "I am Tabarnian!” (¡Soy tabarnés!). Another slogan was painted on a bus which brought the demonstrators: “The joke is over. Long live Tabarnia!” (¡Se ha acabado la broma, jviva Tabarnia!) ${ }^{47}$. The national anthem was sung as well, while all residents of Tabarnia (tabarneses), Catalans, Spaniards, and Europeans were called upon to join the rally. Independence symbols on the balconies of nearby apartments were booed ${ }^{48}$. Moreover, the participants read out the manifesto that Casanova delivered during the siege of the city, in which he stressed that he was fighting for the freedom of the king and the entire Spain ${ }^{49}$.

This pre-emptive action directed against the nationalists had a clearly defined goal: to instil doubt in those who would come there on September $11^{\text {th }}$ to reproduce the act which Tabarnia had performed. Thus, Boadella underlines, "they are going to feel ill at ease. They won't know whether (Casanova) was their patriot or enemy. We have undermined their exclusive right to their symbol"50. Such an action makes sense, as "destruction of the vehicle of memory does not have to be literal, obscuring it suffices" ${ }^{\prime 1}$. In this fashion, representatives of Tabarnia sought to endow the Casanova monument - a vehicle of memory - with a different function of memory than it had been assigned by Catalan nationalists. It was not their objective to (physically) destroy the monument, but to deconstruct its meaning, i.e. to de-nationalize it and lend it an all-Spanish dimension of memory ${ }^{52}$. The choice of the place should be considered well calculated, given that "a monument with its correspondingly structured surroundings is a site of concentrated semiosis" Also, a particular symbolic domain develops around it, governed by and imbued with a specific vision of memory and past on which the memory draws and which

47 Blanchar 2018; La Plataforma por Tabarnia inicia su marcha frente al monumento a Rafael Casanova, icono del soberanismo, 2018.

48 Ibidem.

49 Tabarnia convoca manifestación el 25 y reivindicará a Casanova "un español” con una ofrenda y el himno nacional, 2018.

50 Boadella 2018, p. 160.

51 Kula 2002, p. 213.

52 Ibidem, p. 260.

53 Nijakowski 2006, p. 83. 
it represents: "the group claiming the right to a symbol attempts to challenge the symbolic ascendancy of the group in whose domain the symbol has been found so far" ${ }^{\prime 4}$. In this sense, the Tabarnists strove to show that the Casanova monument is a shared Spanish symbol, as opposed to being exclusively Catalan and nationalist one. The assault on the symbolic domain of the nationalists shows how the ashes of Casanova became an ante in the fight for memory and space in Catalonia, confirming what Pierre Nora noted, namely that the "lieux de mémoire are fundamentally remains" ${ }^{\prime \prime}$. The monument of Casanova can also be described as mirror-memory, which does not reflect history; what a given group wishes to find in it is difference and its inherent reflection of identity ${ }^{56}$.

Importantly enough, the memory of the defeat of 1714 - epitomized through the figure of Rafael Casanova - is directly linked and harmonizes in the nationalist discourse with the memory of the recent events in Catalonia, i.e. the illegal independence referendum and the proclamation of the Republic of Catalonia, suspension of its autonomy as well as detention and later conviction of people responsible for the events. This symbiosis of memory is perfectly exemplified by the lazo amarillo (fig. 2) ribbon painted around the Casanova monument, which symbolized the imprisoned Catalan politicians. In other words, while the flowers laid by the nationalists on September $11^{\text {th }}, 2018$, were a token of the fight against and loss to the Bourbons in 1714, the lazo amarillo stripe around the monument was a reference to contemporary events. Thus, Catalan historical memory was reinforced, regenerated and recreated in the process of nationalist social engineering. In this sense, the pre-emptive commemoration by the supporters of Tabarnia in March 2018 was a performative act. As Paul Connerton asserts, "ritual is a performative language. A performative utterance does not provide a description of a certain action. The utterance of the performative itself constitutes and action" ${ }^{\text {"5 }}$. This was the goal that Tabarnia sought to accomplish: the rally at the Casanova monument was an attempt to change its significance, from a local-nationalist to an Spanish-wide one.

Also in March 2018, Tabarnia staged a historical reconstruction in Caspe, which revisited the notorious compromise of 1412, featuring representatives of the kingdoms of Aragon, Valencia, the Baleares, and the County of Tabarnia (instead of the County of Barcelona). The route of the event spanned Castillo de Monzón (Huesca) and Villanueva de Siguena (Huesca). Albert Boadella, who played Ferdinand I of the House of Trastámara, was crowned as the king of the Tabarno-Arag-

\footnotetext{
54 Ibidem, p. 113.

55 Nora 2008, p. 24.

56 Ibidem, p. 32.

57 Connerton 2012, p. 123.
} 


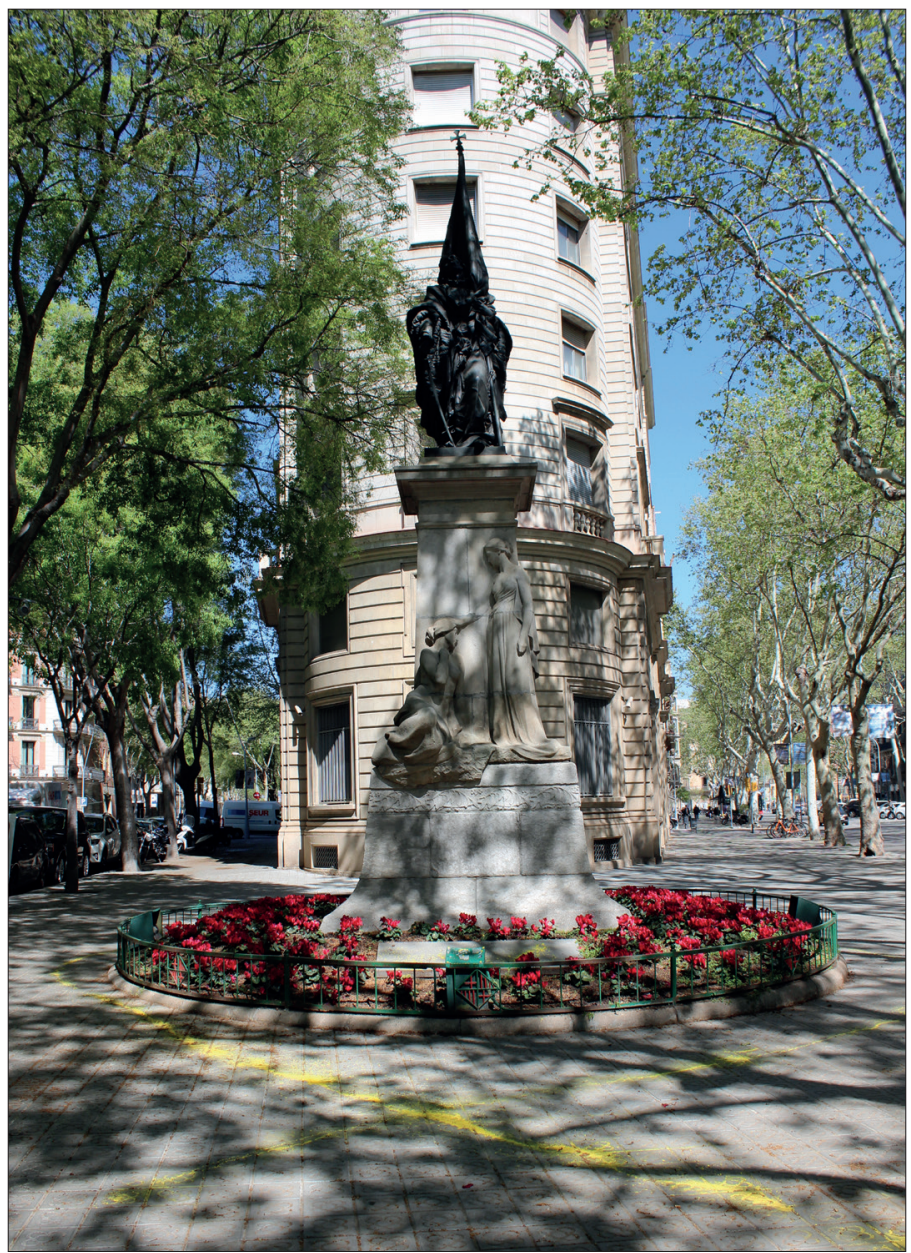

Fig 2. The monument to Rafael Casanova in Barcelona, with lazo amarillo painted around it

Source: photographs by the author

onese Crown (la corona tabarnoaragonesa) $)^{58}$. That was a direct, sarcastic reference to the term "Catalan-Aragonese Crown" (la corona catalanoaragonesa) which, though unfounded in historical fact, is widely used in the discourse of Catalan nationalists. Catalonia has never been a kingdom or had its own kings. On the one hand, the notion of la corona tabarnoaragonesa was intended to expose the absurdity of such manipulations and, on the other, emphasize that a member of the House of Trastámara was chosen upon consent of the representative of the

58 Fidalgo 2018a. 
County of Barcelona, deputized for in the reconstruction by the representative of the County of Tabarnia. Information concerning the event was communicated through a Twitter account named Tabarnia Today: “The Tabarno-Aragonese Crown. Tabarnia is signing a new compromise of Caspe. Tomorrow, at the castle of Monzón (Huesca), with the envoys of the Kingdom of Aragon, the Kingdom of Valencia, the Kingdom of the Baleares and the County of Tabarnia"59. In this case, the undertaking was a "form of upholding memory by way of a quasi-theatrical performance" 60 . Reconstructing the Compromise of Caspe Tabarnia not only sought to overshadow the nationalist memory, but also draw on the past of Catalonia, deliberately opting for an event that the nationalist discourse denounces as "the iniquity of Caspe" (la iniequitat de Casp), which installed the foreign House of Trastámara in Catalonia. The idea was to take over a vehicle of memory used by Catalan nationalists and strip it of the content it has been invested with. In addition, the reconstruction drew attention to the fact that Catalan nationalists exploit the history of medieval Aragon for their particular political goals.

In March 2018, Boadella also travelled to Waterloo in Belgium, where Carles Puigdemont ended up having left Catalonia after the referendum in October 2017. This time, Boadella chose performance with banners and music. Accompanied by Tomas Gaush, member of Tabarnia, he danced and sang outside the house where Puigdemont stayed, holding umbrellas in the colours of the Catalan senyera, and declaring the former to be a "fake president". Also, both left a letter addressed to Puigdemont in his letter box. One of the banners they held read "No to Catalonia without Spain" (No a una Cataluña sin España). Boadella thus tried to desacralize another site associated with the supporters of separation from Spain. As he put it, "we have come here (to Waterloo), to meet the "fake" president, hold a "lowest-level" conference with the legal president, that is myself, and the unlawful president, that is him (Puigdemont)" ${ }^{16}$. The performative nature of the act, consisting in repetition of certain words, gestures, symbols, and colours was quite in line with Tabarnia's strategy to expose and ridicule the absurdities of Catalan nationalism.

April 2018 saw Tabarnia lay flowers in yet another site, namely the monument of the Catalan politician and general Juan Prim i Prats (1814-1870) - one of Spain's foremost generals of the nineteenth century - in Reus, a Catalan town considered to be a bastion of the supporters of independence. As with Casanova, the general's manifesto was read out, in which the author had invoked shared Catalan and Spanish values. Moreover, they reconstructed the famed battle of Tetuán (1859-1860),

\footnotetext{
59 Tabarnia Today 2019.

${ }^{60}$ Kula 2002, p. 177.

61 Suanzez 2018.
} 
in which the general fought with Catalan volunteers. Also, the Spanish anthem in Catalan to the words of Marta Sánchez was sang in the square where the monument stands, and the people gathered chanted slogans such as "Long live free Catalonia!" (Visca Catalunya Lliure!), "Reus, Spanish and Catalan!” (¡Reus, español y catalán!), "The can’t cheat us, Catalonia is Spain” (¡No nos engañan, Cataluña es España!), "Long live Spain!” (¡Viva España!), “Long live Catalonia!” (¡Visca Catalunya!). The president of the Platform for Tabarnia, Miguel Martínez, stated that the idea was to "liberate the general from Catalan independentism"62. A castell (human tower) - one of the most recognizable symbols of Catalonia - was also built to mark the occasion. A flag of Spain was mounted at the top of the monument, while a flag of Tabarnia was affixed to the sword held by the statue ${ }^{63}$. "The Government of Tabarnia" (Govern de Tabàrnia) posted a video showing all that on its Twitter account ${ }^{64}$. According to one of the participants, general Prim is epitomizes the fact that "love for Spain, your country, and love for Catalonia, your land, are by all means possible; both feelings are equally strong and in no way mutually exclusive" 65 .

Another noteworthy event took place on April 23 ${ }^{\text {rd }}, 2018$, on the day of Sant Jordi. As is the tradition of the festival, numerous acclaimed writers present their books, while visitors can purchase them with the author's autograph. Albert Boadella, who set up his stand on a boat moored in the harbour of Barcelona, used the opportunity to sign his book entitled "Long live Tabarnia!” (¡Viva Tabarnia!). He remained on the boat and did not go on land, in accordance with the promise made in 2006 that he would never again make any public act on Catalan land. The boat where the book-signing act took place functioned as a maritime consulate of Tabarnia, while the whole event constituted a "satirical reverse of independentism"66. Boadella dedicated the first copy of his book to Carles Puigdemont, "so that he may finally comprehend the disaster he has provoked" ${ }^{67}$. The video capturing the moment of signing that particular book was posted on the Twitter account of the "Govern de Tabàrnia"68.

Tabarnia is known for taking advantage of dates, symbols and events which are important for the Catalan nationalists, only to re-interpret them using an anti-nationalist paradigm. For instance, on October $27^{\text {th }}, 2018$, the Tabarnists

${ }^{62}$ El movimiento Tabarnia rinde tributo a Prim en Reus y defiende la unidad, 2018.

${ }^{63}$ Villarreal 2018, p. 17; Fidalgo 2018b.

${ }^{64}$ Tabarnia Today 2019.

${ }^{65}$ Villarreal 2018, p. 17.

${ }^{66}$ Doria 2018, p. 46.; Boadella se sube a un catamarán para dedicar a Puigdemont su libro sobre Tabarnia, 2018; Albert Boadella firma sus libros en un catamarán en el puerto de Barcelona para "no pisar suelo catalán", 2018.

${ }^{67}$ Boadella se sube a un catamarán para dedicar a Puigdemont su libro sobre Tabarnia, 2018.

${ }^{68}$ Govern de Tabàrnia 2018b. 
once again employed the mode of performance to hold a symbolic funeral of the Catalan republic. For this purpose, 155 people were to be gathered in $\mathrm{Pa}$ seo Lluís Companys in Barcelona; the number was anything but random, as it referred to Article 155 of the Spanish Constitution, under which the government in Madrid suspended the autonomy of Catalonia after the independence referendum. Ultimately, fewer people took part due to inclement weather. The centre-piece of the funeral was a plastic (voting) urn with the inscription "Generameitat de Catalunya" (a paraphrase of the word "Generalitat", meaning a half of the members of the Catalan parliament) containing yellow ribbons which symbolized the imprisoned Catalan politicians involved in the independence process. Those carrying the urn were dressed in black, the sounds of a funeral march could be heard in the background. The urn was deposited under a wreath in the national colours of Spain; a sign with the flag of Tabarnia and the inscription "Government of Tabarnia" stood at the back. Between them, there was a headstone with its usual "R.I.P." as well as representations of the estelada and lazo amarillo ${ }^{69}$. The epitaph read: "Here lie the remains of the Catalan republic which existed for 8 seconds. After a year, it ceased to exist without international recognition at 5:14 p.m., October $27^{\text {th }}, 2018^{\prime \prime 70}$. Thus, a symbolic reference was made to the year 1714, which in the discourse of the nationalists is the date of the abolition of Catalan freedoms and rights by Philip V of Spain, whose descendant Philip VI is the current king of Spain. Those gathered chanted "Long live Spain, long live Tabarnia, long live Catalonia, and farewell to you, Republic!” (Visca Espanya, visca Tabarnia, visca Catalunya i adéu república!). Naturally, videos documenting the event were posted in Tabarnia's social media, specifically on the official Twitter accounts of "the Govern de Tabarnia" ${ }^{\prime 1}$ and the movement ${ }^{72}$.

According to Paul Connerton, performativity is an act of speech, and tends to be expressed in the iteration of certain verbs and pronouns, while the performative act itself is conveyed through particular postures, gestures, or movements ${ }^{73}$. The symbolic performative acts which Tabarnia often utilizes includes slogans: paraphrases of their equivalents used by the Catalan nationalists. The table below presents some of the most important slogans of Tabarnia, along with the nationalist prototypes by which they were inspired.

69 Tabarnia organiza el "funeral de la república catalana” un año después de la DUI: "Que tenga un descanso eterno", 2018.

70 Tabarnia da por muerta la república catalana y organiza su funeral, 2018.

${ }^{71}$ Govern de Tabàrnia 2018c.

72 Barcelona is not Catalonia 2018.

73 Connerton 2012, pp. 123-125. 


\begin{tabular}{|c|c|}
\hline Slogans used by the supporters of Tabarnia & Slogan used by Catalan nationalists \\
\hline $\begin{array}{l}\text { ¡Libertad para Tabarnia! (Freedom for Tabar- } \\
\text { nia!) }\end{array}$ & Freedom for Catalonia! \\
\hline $\begin{array}{l}\text { ¡Cataluña roba a Tabarnia! (Catalonia is rob- } \\
\text { bing Tabarnia!) }\end{array}$ & Espanya ens roba! (Spain is robbing us!) \\
\hline $\begin{array}{l}\text { ¡Fuera fuerzas de ocupación de Tabarnia! (Away } \\
\text { with the forces occupying Tabarnia!) }\end{array}$ & $\begin{array}{l}\text { Fora les forces d'ocupació! (Away with the occu- } \\
\text { pation forces!) }\end{array}$ \\
\hline Tabarnia is not Catalonia! & Catalonia is not Spain! \\
\hline $\begin{array}{l}\text { ¡Las calles de Tabarnia siempre serán nuestras! } \\
\text { (The strees of Tabarnia will always be ours!) }\end{array}$ & $\begin{array}{l}\text { Els carrers seràn sempre nostres! (The streets } \\
\text { will always be ours!) }\end{array}$ \\
\hline $\begin{array}{l}\text { ¡Libertad presos tabarneses! }{ }^{74} \text { (Free the prison- } \\
\text { ers of Tabarnia!) }\end{array}$ & $\begin{array}{l}\text { Llibertat presos polítics! (Free political prison- } \\
\text { ers!) }\end{array}$ \\
\hline $\begin{array}{l}\text { ¡No al expolio de Barcelona y Tarragona! (No to } \\
\text { exploitation of Barcelona and Tarragona!) }\end{array}$ & Espanya ens expolia! (Spain exploits us!) \\
\hline
\end{tabular}

Source: author's surveys

Another major strategy of the Tabarnists is to emphasize across social media that Tabarnia is a part of Spain, thereby striving to achieve the opposite effect to what nationalists try to accomplish. While the national discourse focuses on underlining differences between Catalonia and Spain to instil the conviction that Catalonia is not Spain, supporters of Tabarnia invariably accentuate their affiliation with Spain, whose inseparable part they do feel to be. As an example, on could quote the singular iunctim between Tabarnia and Spain formulated on the basis of historical events which are crucial to all Spaniards, and posted on the Facebook profile of the movement:

It was in Tabarnia that in 1493 Columbus announced the discovery of America to the Catholic Kings.

It was in Tabarnia that in 1615 Don Quixote marched.

It was in Tabarnia that in 1641 the first newspaper in Spanish came out.

It was in Tabarnia that in 1868 the first tweezers were made.

Who dares to say we are not Spain? ${ }^{75}$

${ }^{74}$ The slogan "Free the prisoners of Tabarnia" was created when a number of supporters of Tabarnia, who had been removing independence symbols - especially the lazos amarillos - from the Catalan public space, were arrested by the Catalan police. Cf. Cataluña detiene a 7 tabarneses por limpiar lazos.

${ }^{75}$ Barcelona is not Catalonia 2019b. 


\section{CONCLUSIONS}

The example of Tabarnia shows that critical thought does not have to be politicized, i.e. associated with particular public institutions or - even less so - with partisanship. The idea behind that popular neologism is all about making efforts to demolish the wall of nationalism. Comparing life in Catalonia to life in the capital of Northern Ireland, Sergio Fidalgo, a critic of nationalist divides, writes thus:

We live in Belfast 2019: we do not kill or beat each other up, but there exist two separate communities which look at each other with distrust. The separatists have built a wall, and they will decide when to tear it down. But they no longer have the hegemony. We are in a better situation, because thousands of Catalans are now aware of what nationalism is and keep their fingers on the pulse ${ }^{76}$.

In a situation where a proportion of the Spanish political class team up with nationalists for reasons of their own particularistic interests which adversely affect the unity of Spain, a project relying on joke and satire may paradoxically contribute to the failure of the nationalist project. It may not accomplish its complete collapse, but it is certain to undermine and fragment it. Polish sociologist Krzysztof Pomian argues that "if a story is deemed a fairy tale, its substance is denied realness, and thus it is expulsed from history; the converse applies in equal measure: if anything is proven to be fictitious, the story about it is denied a place in history, and considered a product of fabulation"77. However, the matter with Tabarnia is not that simple. Although its chief province is fiction, the strategy of ridiculing Catalan nationalism is brought to bear for the sake of truth and history, hence it does not deserve to be expulsed. Especially so that its actions expose the falsehoods of the social engineering project in Catalonia, becoming the reverse of the process described by Pomian. In the age of crisis of historical knowledge, the tactics of the Tabarnists encourages reflection on Catalonia's past and its associations with the rest of Spain, which are subject to constant manipulation in the nationalist discourse. This is precisely the goal of the movement: the fictitious Tabarnia attempts to demonstrate the illusory nature of the Catalan republic.

Marta García Aller, who defines Tabarnia as a "post-truth transformed into an antidote", aptly underlines that the Tabarnists have introduced a new quality into the Catalan discourse of identity, something which the adherents of the Catalan-Spanish

\footnotetext{
76 Fidalgo 2019.

77 Pomian 2006, p. 10.
} 
unity were unable to offer ${ }^{78}$. The strategy of trolling, of media-based action, social media in particular, exasperates and hampers nationalists, compelling them to counter-offensive. One should ask, however, whether such a philosophy of action could backfire on Tabarnia? After all, the aforementioned Catabàrnia, created in response to the original joke, openly declares its willingness to join the republic of the nationalists. Let us note that Boadella also admits the possibility of abandoning the virtual in favour of the real. As he claims, "we will go as far as the independentists will try to reach. If another unilateral declaration of independence is made, we will act to make Tabarnia a reality"79. The originators of Tabarnia - even though they use jokes, satire, or irony to criticize and ridicule the nationalists - have in fact engaged in a debate with the latter, so what was initially supposed to be a joke becomes increasingly serious (Boadella himself repeated on many occasions that one cannot talk with the nationalists because it is doomed to failure from the start). Given such a binary relationship, Tabarnia may seem to be a Derridean pharmakon (remedy), which loses its curative effect when it transforms into its own opposite ${ }^{80}$.

In my opinion, the strength of Tabarnia lies in the fact that it provides an effective antidote to Hispanophobia that Catalan nationalism feeds on. If, in the case of Hispanophobia, the aim is "to expunge Spain and whatever is Spanish from the indigenous collective that is loyal to nationalism" ${ }^{81}$, Tabarnia seeks to reverse the process, and erase nationalist lies, half-truths and manipulations from the Catalan public space.

\section{SATIRE IN THE SERVICE OF HISTORY. ON THE PHENOMENON OF TABARNIA IN CATALONIA}

\section{Summary}

This paper is sets out to analyze a grassroots social movement functioning in Catalonia under the name of Tabarnia. Its fundamental strategy consists in using satire, joke, or irony, as it carries out happenings, historical reconstructions or performances to mimic nationalist attitudes and behaviours; as a result, the latter are weakened and rendered banal. Actions undertaken as part of the strategy aim to manifest Catalanness by means of what is Spanish. In this context, the author cites events organized by the supporters of Tabarnia, which in fact amount to a mimetic game played with the discourse of the nationalists.

78 García Aller 2018.

79 González 2018. A similar view is expressed by Vives. See Vives 2018, p. 45. It may be added that when they speak of making Tabarnia a new autonomous community the adherents of the movement invoke Articles 143, 144 and 151 of the Spanish Constitution. Cf. Tabarnença. El 23 de abril queda fijado como el Día de Tabarnia.

80 See Derrida 1981, pp. 61-117.

${ }^{81}$ Pérez Velasco 2015, p. 74. 


\section{Bibliography}

Alandete D., Baquero S. 2017, El independentismo a través del espejo de Tabarnia [online]. El País, 28 de diciembre [access: 2019-12-21]. Available at: <https://elpais.com/politica/2017/12/26/actualidad/1514316764_370387.html?rel=mas >.

Amorós M. 2018, Las mujeres coraje de Balearnia [online]. El Mundo, 13 de marzo [access: 2019-1212]. Available at: <https://www.elmundo.es/cronica/2018/03/13/5aa5748122601d4a288b45d9. html>.

Argumentos histórico-políticos para la independencia de Tabarnia [online]. Anotaciones de Jvier Barraycoa, 2017, 28 de diciembre [access: 2019-12-20]. Available at: <https://barraycoa. com/2017/12/28/argumentos-historico-politicos-para-la-independencia-de-tabarnia/>.

Arrufat C. 2015, Tabarnia. Orígen y definición [online]. Barcelonahoy, 2 de septiembre [access: 201912-120]. Available at: <https://www.barcelonahoy.es/tabarnia-origen-y-definicion>.

Balcells A. 2008, Llocs de memòria dels catalans, Barcelona.

Bandera de Tabarnia oficial [online]. Tabarnia [access: 2019-12-20]. Available at: <https://www. tabarnia.org/tienda/producto/bandera-tabarnia-oficial/?fbclid=IwAR2aPHi7bWHRCeillmhHE4uR1f6m_9xBnXJ-fR1FcTq51-giOMoRWG0pYJw>.

Barcelona is not Catalonia 2018 [online]. Twitter [access: 2019-12-20]. Available at: $<$ https://twitter. com/Bcnisnotcat_/status/1056250058650382336>.

Barcelona is not Catalonia 2019a [online]. Facebook [access: 2019-12-19]. Available at: <https:// www.facebook.com/bcnisnotcat/>.

Barcelona is not Catalonia 2019b [online]. Facebook [access: 2019-12-19]. Available at: $<$ https://www. facebook.com/bcnisnotcat/photos/a.592121687467034/2949498368396009/?type=3\&theater $>$.

Baudrillard J. 1981, Simulacres et simulation, Paris.

Billig M. 2008, Banalny nacjonalizm, przeł. M. Sekerdej, Kraków.

Blanchar C. 2018, La platforma por Tabarnia exhibe músculo y se manifesta en Barcelona [online]. El País, 4 de marzo [access: 2019-12-20]. Available at: <https://elpais.com/ccaa/2018/03/04/catalunya/1520162880_273146.html>.

Boadella A. 2018, ¡Viva Tabarnia!, Barcelona.

Boadella se sube a un catamarán para dedicar a Puigdemont su libro sobre Tabarnia, 2018 [online]. ABC, 23 de abril [access: 2019-12-20]. Available at: <https://www.abc.es/espana/catalunya/politica/abci-boadella-sube-catamaran-para-dedicar-puigdemont-libro-sobre-tabarnia-201804231301_noticia.html>.

Cataluña detiene a 7 tabarneses por limpiar lazos [online]. Tabarnia [access: 2019-12-20]. Available at: <https://www.tabarnia.org/web/cataluna-detiene-a-7-tabarneses-por-limpiar-lazos-2/>.

Connerton P. 2012, Jak społeczeństwa pamiętają, transl. M. Napiórkowski, Warszawa.

Delgado Á. 2018, ¿Y si creamos "Palmarnia"? [online]. El Mundo, 4 de enero [access: 2019-12-12]. Available at: <https://www.elmundo.es/baleares/2018/01/04/5a4dfddd22601d991c8b45aa.html>.

Delgado Sánz E. 2018, Albert Boadella: «Si los independentistas hicieran las leyes, yo estaría en la cárcel [online]. ABC, 16 de abril [access: 2019-12-13]. Available at: <https://www.abc.es/espana/ abci-albert-boadella-si-independentistas-hicieran-leyes-estaria-carcel-201804160212_noticia.html\#ns_campaign=mod-sugeridos\&ns_mchannel=relacionados\&ns_source $=$ boadella-si-los-independentistas-hicieran-las-leyes-yo-estaria-en-la-carcel\&ns_linkname=noticia. foto.local\&ns_fee=pos-2>.

Derrida J. 1981, Plato’s Pharmacy, [in:] idem, Dissemination, trans. B. Johnson, Chicago, pp. 61-117. 
Discurso del presidente de Tabarnia, Albert Boadella 2018 [online]. YouTube [access: 2019-12-20]. Available at: <https://www.youtube.com/watch?v=7knBbVQs6os $>$.

Dolça Catalunya 2019 [online]. Dolça Catalunya [access: 2019-12-20]. Available at: <https://www. dolcacatalunya.com/>.

Doria S. 2018, En consulado flotante de Tabarnia, ABC, 24 de abril, p. 46.

El movimiento Tabarnia rinde tributo a Prim en Reus y defiende la unidad, 2019 [online]. La Razón, 26 de noviembre [access: 2019-12-13]. Available at: <https://www.larazon.es/local/cataluna/elmovimiento-tabarnia-rinde-tributo-a-prim-en-reus-y-defiende-la-unidad-JP18068717/> .

Entrevista al creador de Tabarnia, Daniel de la Fuente, en Espejo Público, 2018, 25 de junio [online]. YouTube [access: 2019-12-20]. Available at: <https://www.youtube.com/watch?v=LiQV-O_iSgk> .

Fidalgo S. 2018a, Plataforma por Tabarnia reeditará el "compromiso de Caspe" para escoger presidente entre Boadella y Puigdemont [online]. elCatalán.es, 16 de marzo [access: 2019-12-20]. Available at: $<$ https://www.elcatalan.es/plataforma-por-tabarnia-reeditara-el-compromiso-de-caspe-para-escoger-presidente-entre-boadella-y-puigdemont>.

Fidalgo S. 2018b, El monumento a Prim, en Reus, engalando con la rojigualda a los sones del Himno Nacional (vídeo) [online]. elCatalan,es, 8 de abril [access: 2019-12-20]. Available at: $<$ https:// www.elcatalan.es/el-monumento-a-prim-en-reus-engalanado-con-la-rojigualda-a-los-sonesdel-himno-nacional-video>.

Fidalgo S. 2019, En Cataluña vivimos en Belfast 2019: no nos matamos pero nos miramos con recelo [online]. El Mundo, 26 de abril [access: 2019-04-27]. Available at: <https://www.elmundo.es/ papel/lideres/2019/04/26/5cbee07321 efa0fc528b45ba.html>.

García Aller M. 2018, Por qué Tabarnia está sacando de quicio a los independentistas [online]. El Independiente, 4 de marzo [access: 2019-12-12]. Available at: <https://www.elindependiente. com/politica/2017/12/27/por-que-tabarnia-sacando-quicio-independentistas/\#gs.jjYBHaU>.

González G. 2018, Los impulsores de Tabarnia están dispuestos a ser “una amenaza al independentismo" [online]. El Mundo, 16 de enero [access: 2019-12-11]. Available at: $<$ https://www.elmundo. es/cataluna/2018/01/16/5a5dda91e5fdeae7238b45e9.html $>$.

Govern de Tabàrnia 2018a [online]. Twitter [access: 2019-12-20]. Available at: <https://twitter.com/ governtabarnia/status/982938786127630338>.

Govern de Tabàrnia 2018b [online]. Twitter [access: 2019-12-20]. Available at: <https://twitter.com/ governtabarnia/status/988356618059436032>.

Govern de Tabàrnia 2018c [online]. Twitter [access: 2019-12-20]. Available at: <https://twitter.com/ governtabarnia/status/1056217817761112064>.

Govern de Tabàrnia 2019 [online]. Twitter [access: 2019-12-20]. Available at: <https://twitter.com/ governtabarnia>.

https://tabarnia.org/tienda/>.

Kubiaczyk F. 2018, Catalonia 2018. Clashing Identities in Public Space, Studia Europaea Gnesnensia 18 , pp. 245-280.

Kula M. 2002, Nośniki pamięci historycznej, Warszawa.

La Constitución es el último salvavidas de Tabarnia, Govern Tabarnia <https://www.tabarnia.org/ web/la-constitucion-espanola-es-la-ultima-esperanza-de-tabarnia/>.

La Plataforma por Tabarnia inicia su marcha frente al monumento a Rafael Casanova, icono del soberanismo, 2018 [online]. RTVE.es, 4 de marzo [access: 2019-12-20]. Available at: <http://www. rtve.es/noticias/20180304/plataforma-tabarnia-se-concentra-frente-monumento-rafael-casanova-icono-del-soberanismo/1688720.shtml>. 
Latorre R. 2017, Tabarnia ha existido siempre [online]. El Mundo, 29 de diciembre [access: 2019-1212]. Available at: <https://www.elmundo.es/opinion/2017/12/29/5a454a24ca4741a2098b46b6. html>.

Levinson P. 1998, Soft Edge: Natural History and Future of the Information Revolution, London-New York.

Mapa de Tabarnia. Ya está disponible el primer mapa de España que incluye Tabarnia [online]. Tabarnia [access: 2019-12-13]. Available at: <http://tabarnia.org/web/wp-content/uploads/comunidades-autonomas-espan\%CC\%83olas-con-tabarnia.jpg $>$.

Nace Geronia, la plataforma para reivindicar la españolidad de Gerona, 2018 [online]. ABC, 16 de febrero [access: 2019-12-12]. Available at: <https://www.abc.es/espana/catalunya/abci-nace-geronia-plataforma-para-reivindicar-espanolidad-gerona-201802161314_noticia.html>.

Nijakowski L.M. 2006, Domeny symboliczne. Konflikty narodowe i etniczne w wymiarze symbolicznym, Warszawa.

Nora P. 2008, Pierre Nora en Les lieux de mémoire, transl. L. Masello, Montevideo.

Pérez Velasco V. M. 2015, Hispanofobia, Málaga.

Pomian K. 2006, Historia. Nauka wobec pamięci, Lublin.

Suanzez P.R. 2018, Boadella lleva el circo de Tabarnia a Waterloo: “¡Carlitos!, sal, no te escondas detrás de las cortinas” [online]. El Mundo, 22 de marzo [access: 2019-12-20]. Available at: <https:// www.elmundo.es/cataluna/2018/03/22/5ab36d69268e3eb03b8b45ab.html>.

Tabarnença. El 23 de abril queda fijado como el Día de Tabarnia [online]. Tabarnia [access: 201912-19]. Available at: <https://www.tabarnia.org/web/el-23-de-abril-queda-fijado-como-el-diade-tabarnia/>.

Tabarnia - Tienda 2019 [online].Tabarnia [access:2019-12-20]. Available at: < https://tabarnia.org/ tienda/categoria-producto/camisetas/>.

Tabarnia convoca manifestación el 25 y reivindicará a Casanova "un español" con una ofrenda y el himno nacional, 2018 [online]. EuropaPress, 6 de febrero [access: 2019-12-12]. Available at: $<$ https://www.elperiodico.com/es/politica/20180206/tabarnia-convoca-manifestacion-el-25-y-reivindicara-a-casanova-un-espanol-con-una-ofrenda-y-el-himno-nacional-6605336>.

Tabarnia da por muerta la república catalana y organiza su funeral, 2018 [online]. El Mundo, 27 de octubre [access: 2019-12-20]. Available at: <https://www.elmundo.es/cataluna/2018/10/27/5bd4b385e5fdeada1d8b45b2.html >.

Tabarnia Group 2019 [online]. Facebook [access: 2019-12-19]. Available at: <https://www.facebook. com/groups/Tabarnia/>.

Tabarnia ORG 2019 [online]. Facebook [access: 2019-12-19]. Available at: <https://www.facebook. com/TabarniaORG/>.

Tabarnia organiza el "funeral de la república catalana" un año después de la DUI: "Que tenga un descanso eterno", 2018 [online]. lasexta.com, 27 de octubre [access: 2019-12-20]. Available at: $<$ https://www.lasexta.com/noticias/nacional/tabarnia-organiza-el-funeral-de-la-republica-catalana-un-ano-despues-de-la-dui-que-tenga-un-descanso-eterno_201810275bd495e00cf2ebf01bf7dfb0.html>.

Tabarnia Today 2019 [access: 2019-12-20]. Available at: <https://twitter.com/TabarniaToday/status/975031801700864000>.

Tabarning: el deporte ecológico de moda en Tabarnia [online]. Tabarnia [access: 2019-12-12]. Available at: <https://www.tabarnia.org/web/tabarning-el-deporte-de-moda-en-tabarnia/>. 
Tomàs N., Puente A. 2018, La xenófoba platforma per Catalunya busca presentarse a las municipales bajo la marca de Tabarnia [online]. elDiario.es, 21 de junio [access: 2019-12-20]. Available at: $<$ https://www.eldiario.es/catalunya/politica/Plataforma-Catalunya-presentarse-municipales-Tabarnia_0_784622352.html>.

Villarreal R. 2018, Tabarnia estrena una versión del himno en catalán, El Mundo, 9 de abril, p. 17. Vives J. 2018, Tabarnia. La pesadilla de los indepes, Madrid.

¿Qué diablos es Catabàrnia?, 2018 [online]. Noticias de Catalunya, 13 de febrero [access: 2019-1213]. Available at: < https://noticiasdecatalunya.com/catabarnia/ $>$.

¿Qué es Tabarnia? El verdadero origen del movimiento [online]. Tabarnia [access: 2019-12-12]. Available at: <https://www.tabarnia.org/web/que-es-tabarnia-el-verdadero-origen-del-movimiento/>.

¿Quién inventó Tabarnia? [online]. Tabarnia [access: 2019-12-12]. Available at: <https://www.tabarnia.org/web/daniel-de-la-fuente-el-autor-de-tabarnia-impedira-que-pxc-utilice-el-nombre/>.

Ya se puede adquirir el Documento Regional de Indetidad de Tabarnia, el "DNI de Tabarnia", [online]. Tabarnia [access: 2019-12-12]. Available at: <https://www.tabarnia.org/web/ya-se-puede-adquirir-el-documento-tabarnes-de-identidad-oficial-el-dni-de-tabarnia/> . 
